\title{
The role of talent management in strategic renewal
}

\author{
Kati Järvi \\ Department of Management and Organization, Hanken School of Economics, \\ Helsinki, Finland and \\ Talent Vectia, Helsinki, Finland, and \\ Violetta Khoreva \\ Department of Management and Organization, Hanken School of Economics, \\ Helsinki, Finland
}

\begin{abstract}
Purpose - The purpose of this paper is to emphasize the role of talent management (TM) in strategic renewal. Furthermore, the authors extend the existing knowledge on the process of TM implementation by underlining particular activities, which are involved in this process during strategic renewal.

Design/methodology/approach - The authors report a qualitative study of a TM program in a Finnish-Swedish Multinational corporation undergoing major strategic renewal. The data consist of 46 semi-structured interviews and secondary data.

Findings - The role of TM in the context of strategic renewal is to provide the conditions for the self-initiation and identification of potential change agents and for the development of the talented employees to perform in their roles of change agent. In the context of strategic renewal, TM process consists of identification of key projects to address critical business opportunities and challenges, the identification of talented employees to execute them, and the identification and creation of key positions.

Research limitations/implications - The authors encourage scholars to explore the empirical settings characterized by change and unpredictability in more detail, and thus examine the role of talented employees and TM in other specific contexts. Future studies are also encouraged to study other cultural settings and examine to what degree the process of TM implementation may positively influence attitudes and behaviors of talented employees and, consequently, the overall organizational performance.

Practical implications - This study offers practical advice for top management and HR managers. First, the process of TM implementation during strategic renewal should start with the identification of "must-win-battles" that can have a more profound impact on change. Furthermore, top management should allow and enable motivated potential talented employees to volunteer for the job of aiding company-wide changes. Next, top management should provide the talented employees with the space to come up with novel ideas and conceive new business opportunities. Finally, the importance of transparent and spot-on evaluation criteria should be emphasized.
\end{abstract}

Originality/value - The study contributes to advancing our understanding of TM and strategic management in practice.

Keywords Employee behaviour, Europe, Multinational companies, Employees, Organizational change,

Qualitative methods

Paper type Research paper

\section{Introduction}

The research field of talent management (TM) has received a remarkable degree of academic and practitioner interest (Collings et al., 2019; Collings and Isichei, 2018; De Boeck et al., 2018; Krishnan and Scullion, 2017; McDonnell et al., 2017; Meyers et al., 2019; Vaiman et al., 2017; Van den Broek et al., 2018). TM has become a vital component of the world's most influential academic and practitioner-oriented conferences (i.e. Academy of Management Conference;

(C) Kati Järvi and Violetta Khoreva. Published by Emerald Group Publishing Limited. This article is published under the Creative Commons Attribution (CC BY 4.0) licence. Anyone may reproduce, distribute, translate and create derivative works of this article (for both commercial and non-commercial purposes), subject to full attribution to the original publication and authors. The full terms of this licence may be seen at http://creativecommons.org/licences/by/4.0/legalcode 
ER

42,1

Global Talent Management Conference). Furthermore, several influential academic journals have devoted special issues to this research domain (i.e. Employee Relations in 2016).

Nowadays organizations operate in increasingly dynamic environments, characterized by substantial and often unpredictable technological, political and economic change (Oreg et al., 2018; Wee and Taylor, 2018). More and more organizations need to transform themselves at one time or another to survive. Consequently, the capability of strategic renewal becomes a key consideration in supporting the organization's long-term survival and prosperity (Ocasio et al., 2018; Pratap and Saha, 2018; Riviere et al., 2018; Schmitt et al., 2018). To the best of our knowledge, none of the studies have explored the role of TM in the specific context of strategic renewal. This is a serious omission since strategic renewal involves critical changes to organizational activities and outputs as organizations respond to meet the needs of their environment (Albert et al., 2015) and can thus extensively guide the way TM is executed. Guided by this observation, we consider that uncovering the role of TM in embracing and managing strategic renewal requires further attention and can contribute to advancing our understanding of TM.

The aim of our study is thus to examine the role of TM in strategic renewal, and to investigate how TM is implemented during strategic renewal by conducting a qualitative case study with rich data on a TM program in a Finnish-Swedish multinational corporation (MNC), undergoing major strategic renewal. The contribution of our study is twofold. First, we expand the academic understanding of the role of TM in strategic renewal and specify how talented employees, whom "organizations view as unique resources, central to achieving sustained competitive advantage" (Van den Broek et al., 2018, p. 199), contribute to the organization's strategic renewal. Second, we extend the existing knowledge on the process of TM implementation by underlining particular activities, which are involved in this course of action during strategic renewal.

\section{Theoretical background}

To uncover the role of TM in strategic renewal and depict the process of TM implementation during strategic renewal, we first set the stage by defining the core concepts of our study, namely TM and strategic renewal. Then, we discuss the intersection of TM and strategic management literatures to provide motivation for our study.

\section{Defining the terms: talent management and strategic renewal}

TM has been characterized by a mishmash of definitions and theoretical assumptions that has resulted in inconsistent "stories" (Gallardo-Gallardo and Thunnissen, 2016). The lack of agreement led to almost every published article starting with a sentence along the lines of "disturbing lack of clarity regarding the definition, scope and overall goals of talent management." Even though academics have not reached consensus on a single definition of TM, Collings and Mellahi's (2009, p. 304) definition has been the most widely adopted definition in the academic literature (Gallardo-Gallardo et al., 2015). According to this definition, TM is "activities and processes that involve the systematic identification of key positions which differentially contribute to the organization's sustainable competitive advantage, the development of a talent pool of high potential and high performing incumbents to fill these roles, and the development of a differentiated human resource architecture to facilitate filling these positions with competent incumbents and to ensure their continued commitment to the organization."

This definition advocates a more exclusive approach to TM with a focus on particular segments of the workforce (Gallardo-Gallardo et al., 2013). This stands in contrast to more inclusive approaches where all employees are considered as equally valuable to the organization. The level of exclusivity of TM has been one of the central debates in the literature thus far (Collings et al., 2017; Meyers et al., 2013). While some challenge the 
perceived "elitist" underpinning of differentiated TM systems suggesting that those in non-critical roles receive no investment, the focus should be on making informed decisions around the optimum level of talented employees required in these roles and the appropriate level of HR investment for employees in those roles (Becker et al., 2009). The research is not conclusive on the positive impacts of exclusive approach to TM on talented employees' outcomes and more research is certainly required on this topic (Collings et al., 2017; Meyers et al., 2013). In addition, this definition emphasizes a focus on critical roles as opposed to talent in isolation which contrasts with the focus of early work on TM which focused on A-players (Collings and Mellahi, 2009).

The research field of TM also incorporates tensions regarding who is identified as a talented employee (Meyers et al., 2013; Gallardo-Gallardo et al., 2013). According to the subject inclusive approach, all employees are viewed as talented employees whereby every individual's strengths should be harnessed for the organization's benefit (Collings and Mellahi, 2009). In contrast, the object approach highlights individual characteristics of talented employees (e.g. ability, competence, performance, behaviors) (Collings and Mellahi, 2009). According to the object exclusive approach, talented employees are masters of particular competences; they possess commitment to the work at hand and to the organization; and fit to the particular context as employees may not perform in the same way across every situation or context (Gallardo-Gallardo et al., 2013).

\section{Strategic renewal}

Contemporary industries are amorphous, their boundaries are ill-defined. Due to relentlessly changing operating environments, many organizations are currently facing the need to renew themselves. To give an example, digitalization has severely manipulated various industries where organizations, adjusting to the shrinking demands for their former cash-generating products, are forced to make difficult decisions, such as production capacity reduction, restructuring and layoffs (Schneider, 2018). In addition, phenomena such as global outsourcing, healthcare management, bribery, corruption, political risks and poverty add to the challenges faced by organizations (Morris et al., 2016). Finally, competitors that possess fresh ideas and market-penetrating techniques make the sustainable competitive advantage of organizations a remote possibility, intensify the role of chance and luck as its likely explanation (Fitza, 2017). To survive in current times and in the future, organizations are required to strategically renew themselves (Ocasio et al., 2018; Pratap and Saha, 2018; Riviere et al., 2018). Strategic renewal has thus become a key capability in understanding organizational long-term survival and prosperity (Agarwal and Helfat, 2009).

According to the latest systematic review of the various literature streams on strategic renewal (Schmitt et al., 2018), previous literature agrees to disagree on the meaning of the term "strategic renewal" since the term has been freely applied within the different theoretical debates, research domains and empirical contexts. Hence, the two terms that constitute the name strategic renewal have to be discussed. "Renewal" signifies the revitalization, redeployment or replacement of the firm's current organizational attributes (Agarwal and Helfat, 2009). Through renewal, organizations explore and learn entirely new ways of using their core competences and competitive approaches (Floyd and Lane, 2000). "Strategic" signifies actions targeted at the transformation of the core capabilities associated with competitive advantage (Flier et al., 2003). Hence, according to Schmitt et al. (2018), there are three primary, recurrent elements that define the core of the strategic renewal concept. In particular, strategic renewal incorporates a transformation of the organization's core capabilities related to competitive advantage; concerns the entire organization and possesses implications across organizational levels; and is vital to break path dependence and ensure the organizational long-term survival (Schmitt et al., 2018). Based on these

Role of talent management 
ER

42,1

components, Schmitt et al. (2018, p. 85) propose the following definition: "Strategic renewal describes the process that allows organizations to alter their path dependence by transforming their strategic intent and capabilities." Consequently, strategic renewal contains distinct renewal journeys or trajectories describing the underlying patterns of action, which lead to strategic renewal over time (Kwee et al., 2011).

Linking talent management and strategic renewal

Scholars have repeatedly stressed the crucial role of top managers in strategic renewal (Schmitt et al., 2018). With no doubt, senior executives' wisdom, experience and knowledge are conducive for formulating the intent of strategic renewal, coaching initiatives to support the renewal and allocating resources for its implementation (Teixeira and Werther, 2013). However, strategic renewal in organizations is not purely a top-down process driven by top management (Schmitt et al., 2018). It is also an outcome of autonomous behavior initiated outside the top management (Burgelman, 1994). Strategic renewal concerns the refreshment or replacement of resources and capabilities where resources can be intangible and human (Agarwal and Helfat, 2009). In this regard, strategic renewal may refer to the process, content and outcome of human resource refreshment or replacement. The human capital perspective assumes that talented employees are valuable and unique human resources who encompass strategic capital and make valuable contributions to organization's objectives (Collings and Mellahi, 2009; Meyers and Van Woerkom, 2014). In this regard, organizations aiming to succeed in strategic renewal need to include all of their human resources in the transformation, including talented employees.

Besides, strategic renewal is a high-risk, highly uncertain endeavor. While an organization might know the direction where it needs to go (e.g. to become a renewable materials company), the organization might not know precisely what kind of initiatives and actions are required to execute strategic renewal. Strategic renewal requires new kind of thinking as well as the ability to see opportunities beyond what the organization is already executing. In order to contribute to strategic renewal, new kinds of processes, operating models and organizational roles are needed, which might be unclear at the beginning of the strategic renewal process. Talented employees might perform an active role in the execution of this process since they are the employees who make valuable contributions to organizational objectives and possess rare knowledge and skills (Collings and Mellahi, 2009; Morris et al., 2016). Indeed, talented employees are well-skilled, highperforming employees, who frequently take initiative to pursue new ideas and conceive new business opportunities (Cascio and Boudreau, 2016; Meyers and Van Woerkom, 2014). They possess competences and the in-depth knowledge of how to mobilize corporate resources (Farndale et al., 2010). Talented employees are valuable, rare, imitable and non-substitutable strategic assets that enable organizations to implement value-creating strategies (Sparrow and Makram, 2015).

Taken together, we foresee that TM may enact a decisive role in achieving strategic renewal through managing talented employees who may function as a manipulable resource in the organization's strategic renewal. TM might help in overcoming the above issues by developing talents' abilities to take risk, deal with uncertainly and generate new ideas. Careful deployment of TM in the implementation of the organization's strategy may thus bring high economic value and contribute to the organization's strategic renewal.

In the above section, we forecast the potential role of TM in strategic renewal. We anticipate that while in an organizational context that is relatively stable (i.e. there is no (major) change, transformation or renewal), talented employees are typically identified by the organization and occupy key positions, which add to the competitive advantage of the organization (Collings and Mellahi, 2009), the role of TM in strategic renewal may become 
more self-regulating and less defined. In particular, we envision that during strategic renewal talented employees are catalysts of strategic renewal; they generate innovative and unconventional ideas, influence and motivate other employees, bring about change through developing and implementing new processes, models and roles. Furthermore, we envision that during strategic renewal talented employees perform as behavioral role models and articulate a compelling vision to energize other employees to perform beyond expectations. Accordingly, the role of TM in strategic renewal is suggested to equip talented employees with the skills needed, and place them into positions where they can exercise those skills while contributing to strategic renewal. What we lack, however, is whether the described role of TM in strategic renewal holds true in practice. So, the next step is to explore empirically our conceptualization of the role of TM in strategic renewal.

\section{Methods}

We chose a case study as our research strategy. In particular, we conducted a qualitative single case study of a TM program in a Finnish-Swedish MNC. According to Siggelkow (2007, p. 21), case studies are persuasive when there is "something missing in the theory, motivating further research and justifying more refined conceptualization." Case studies are also persuasive when they are used "as inspiration for new ideas" (Siggelkow, 2007, p. 21). Finally, case studies may "sharpen existing theory by pointing to gaps and beginning to fill them" (Siggelkow, 2007, p. 21). Since our aim was to expand the academic understanding of the role of TM in strategic renewal, and extend the existing knowledge on the process of TM implementation, and the context of strategic renewal played an integral real-world role in which the phenomenon (i.e. TM) occurred (Eisenhardt and Graebner, 2007), we determined a case study as a suitable research strategy for our inquiry.

\section{Description of the empirical setting}

The case company is a globally operating MNC, headquartered both in Finland and Sweden (we will refer to it as "the case company"). The case company was originally established as a mining, iron and wood company centuries ago. Later, the mining and metal operations were sold, and the company focused on forestry, pulp and paper. Finally, less than a decade ago, the case company embarked on another transformation journey to become a forest-based renewable materials company. Particularly, the case company aimed to strategically transform itself from a producer of pulp and paper to a renewable materials company. We determined the transformation journey as an attempt of strategic renewal since the case company explicitly aimed at transforming its strategic intent and capabilities by replacing some of its existing paper business with new businesses - such as packaging, biomaterials, and wooden construction - and some of its current products with new products and services based on wood and other renewable materials (Agarwal and Helfat, 2009; Schmitt et al., 2018).

To support the strategic renewal to a forest-based renewable materials company and to renew human resources and their capabilities, the case company introduced several succession planning and leadership programs, among other initiatives. One of these programs was a TM program specifically designed for talented employees (we will refer to it as "the program"). The program was initiated in 2011 and until 2016 five editions of the program have been executed - our data collection covers the period of 2011-2016. During the program talented employees had opportunities to collaborate with peers, think beyond the day-to-day business, learn from external perspectives and share ideas with the top management team. Talented employees were exposed to numerous challenges, including: pushing the boundaries to "rethink" the case company, avoiding drowning in an ocean of information and data and delivering concrete and actionable recommendations at the end of the program. Accordingly, the program was a key vehicle for enabling and driving strategic
Role of talent management 
ER

42,1

80

renewal of the case company through the work of talented employees, and, hence, we chose it as our case study site. As the Executive VP of HR explained to us:

We have set two targets related to the program. One target is that it shall lead to tangible contributions to the continued transformation of [the company]. [...] The second target we're setting that $70 \%$ of the participants will have shifted part in the organization and/or have been promoted within 9 months after the program has come to an end. (Executive VP of HR)

Anyone in the case company could apply to participate in the program. Approximately 200 applicants applied to the program on a yearly basis and, eventually, 12-16 program participants were selected per year. The case company followed an objective exclusive approach toward TM (Gallardo-Gallardo et al., 2013). In particular, the selection process gave weight to each candidate's experience and track record in the case company. However, the most crucial criteria were candidates' motivation, personality and passion for change. The selected talented employees, who became the participants of the program (we will refer to them as "talented employees"), worked on mission-critical projects, guided by the overarching strategic intent of the case company to renew itself.

\section{Data collection and analysis}

We utilized two sources of data - semi-structured interviews and secondary data. The data collection covered retrospectively the first four editions of the program (2011-2015) and in real-time the fifth edition of the program (2015-2016). The main data comprised of semi-structured interviews with 38 talented employees (Table I) - including repeated interviews with the participants of the fifth edition of the program - and with eight respondents with other responsibilities in the program, resulting in 46 semi-structured interviews. The duration of interviews varied from 60 to $90 \mathrm{~min}$. All interviews were recorded with the permission of the respondents and transcribed verbatim.

For the interviews with talented employees, our interview guide consisted of three sections. First, we asked background questions, such as what the respondent's current position and responsibilities in the company were. Second, we asked questions related to program participation, covering the topics of applying and being selected for it (e.g. Why did

\begin{tabular}{|c|c|c|c|c|}
\hline & $\begin{array}{l}\text { Number of } \\
\text { projects }\end{array}$ & Topics of the projects & $\begin{array}{l}\text { Number of } \\
\text { participants }\end{array}$ & $\begin{array}{l}\text { Number of } \\
\text { interviewees }\end{array}$ \\
\hline 2011-2012 & 2 & $\begin{array}{l}\text { 1. Global Responsibility I } \\
\text { 2. Innovation I }\end{array}$ & 12 & 6 \\
\hline 2012-2013 & 3 & $\begin{array}{l}\text { 3. Internal Reorganization } \\
\text { 4. New Market Area for MCC } \\
\text { 5. Supply chain Improvement }\end{array}$ & 14 & 5 \\
\hline 2013-2014 & 3 & $\begin{array}{l}\text { 6. Differentiation } \\
\text { 7. Global Responsibility II } \\
\text { 8. Food Preservation }\end{array}$ & 14 & 7 \\
\hline 2014-2015 & 4 & $\begin{array}{l}\text { 9. Getting A Grip on Time } \\
\text { 10. Innovation II } \\
\text { 11. Product Management } \\
\text { 12. Hidden Value in Supply Chain }\end{array}$ & 16 & 11 \\
\hline 2015-2016 & 4 & $\begin{array}{l}\text { 13. Industrial Digitalization } \\
\text { 14. Insight-Driven Innovation } \\
\text { 15. Leading Edge Supply Chain } \\
\text { Service } \\
\text { 16. Key Account Management }\end{array}$ & 16 & 9 \\
\hline Total & 16 & & 72 & 38 \\
\hline
\end{tabular}

\section{Table I.}

Key projects assigned to the selected talented employees 
you apply for the program?) and being part of the program (e.g. What were you working with during the program? How did you work with your team?). The last section of the interview guide focused on the results of the program participation (e.g. Were there any changes in the way you saw your responsibilities while participating in the program? How did your role evolve while participating in the program? What was the result of your project work?). The interview guide evolved during data collection and its semi-structured format allowed latitude for follow-up questions and discussion.

As already mentioned, in addition to the 38 semi-structured interviews with talented employees, we interviewed eight respondents responsible for the program including the former and current CEO of the company, five members of the top management team (including the Executive VP of HR), and the director of the program at the European business school. Four of these interviews were conducted face-to-face and four over the telephone. These interviews investigated in more detail the purpose of the program and its role in strategic renewal of the company.

The primary empirical material was complemented with secondary data. First, numerous informal conversations were conducted with the Executive VP of HR and the director of the program from the European business school. Second, internal documents such as the company's internal advertising of the program, the program's evaluation reports, which were evaluated by the program participants, and external documents, such as annual reports, newspaper articles and YouTube videos accompanied the primary empirical material. Finally, two seminars, where the Executive VP of HR and the director of the program gave presentations about the program, were attended.

For the analysis of our data, we began with reading the transcripts and secondary data and coding the data. In coding, we utilized a tabula geminus or "twin-slate" coding approach (Kreiner, 2016). This approach incorporates both codes emerging from the language of the respondents/what the researcher sees in the data and theory-based codes. During the coding, we created a hierarchical dictionary of codes and while doing so, grouped our codes to sub-categories and ultimately to higher-level categories reflecting the central interests of our study: the role of TM in strategic renewal and the process of TM implementation during strategic renewal. Thus, open and axial coding (e.g. Corbin and Strauss, 1990) were merged in our coding procedure: rather than creating a freestanding list of codes first and then exploring their relationships, we created a hierarchical dictionary of codes (Kreiner, 2016). Ultimately, we interpreted our emerging findings in the light of existing literature: we contrasted and compared our findings with prior literature to clarify our theoretical contribution emanating from our study.

\section{Findings}

Our findings suggest that the role of TM in strategic renewal is to provide the conditions for the self-initiation, identification and development of talented employees to perform in their roles of change agents. For this reason, during strategic renewal, talented employees act as self-initiated change agents. In their role of change agents, talented employees contribute to the strategic renewal first, by conceiving and designing new business development and internal improvement initiatives; second, by identifying and creating key positions that are of importance for the strategic renewal; and third, by cultivating a culture and proactive mentality for renewal across the organization. Furthermore, our findings indicate that during strategic renewal, TM process consists of identification of key projects to address critical business opportunities and challenges, the identification of talented employees to execute them, and the identification and creation of key positions. We will elaborate on our findings in more detail in the following sections.

Role of talent management 
From 2011 to 2015 during each Autumn, an open invitation to apply to the program was posted in the case company. For the first edition of the program, the open invitation announced that the company was searching for "proven rethinkers who can turn new ideas and approaches into innovative solutions" to "form a small team that would help [the top management team] to rethink and, more importantly, act differently." Thus, potential talented employees self-appointed themselves to participate in the program. In other words, they volunteered to be part of the program and thus, to be part of the process of transforming and changing the case company:

I have chosen to be in the program. That is something I would emphasize strongly; in our transformation, people can volunteer to be a part of [the program] if they want to. (Program participant 2013-2014)

In terms of self-initiation, it is important to understand the reasoning behind this approach from both perspectives, i.e. the case company perspective and the perspective of talented employees. From the case company perspective, self-initiation was determined as the means to identify those talented employees who could create novel ideas and approaches, and be capable of both developing innovative solutions and helping the senior executives to think differently. A conclusion was reached among the senior executives at the onset of the strategic renewal that the required diversity gender, geography, industrial expertise, educational background and thinking - was not there in the top management. Hence, self-initiation was selected as a suitable mechanism to identify and select talented employees, from various kinds of backgrounds, that were "real rethinkers with the motivation and passion for change" and have "the guts needed to actually make it happen," as the advertisements of the program stated. Enabling talented employees to "put up their hands" was vital also to ensure talented employees' continued commitment during and after the program. For talented employees, the participation in the program occurred alongside their day-to-day work and routines. Hence, for some talented employees the combination was extremely challenging timewise. It was thus crucial for the motivation of talented employees to volunteer to participate in the program instead of being, for example, called upon to participate.

From the viewpoint of talented employees, identification as someone who can drive the change and contribute to the transformation of the company sparked self-initiated participation in the program. For this reason, talented employees recognized a potential change agent in themselves and thus applied to the program:

I applied because I believe in the company, I believe in the transformation. I want to be part of it, and I want to find new challenges and new ways to see the world, and to develop myself personally. (Program participant 2015-2016)

When I read the advertisement for this program, everything that was written there was made for me. If you want to question the way we work, if you want to get into something new. The funny thing was than when I read it to my wife, my wife said: "What are you waiting for, why don't you apply - now!" (Program participant 2011-2012)

So why do they apply? I think it comes back to the absolute evidence that we can provide that if you're part of this, you are part of transforming [the company], and there are thankfully enough people that are passionate about driving the transformation. (Executive VP of HR)

We observed that talented employees acted as self-initiated change agents during strategic renewal of the case company. Analogical to the distinction made, for example, between expatriates (i.e. "those who are dispatched by their home companies to international posts") and self-initiated expatriates (i.e. "those who themselves make the decision to move and 
work abroad") (Peltokorpi and Froese, 2009, p. 1096), we determine that talented employees acted as self-initiated change agents as they themselves made the decision to participate in the program.

Among the applicants, the program participants were then selected based on an explicit TM evaluation and review process described in the previous section. Accordingly, in line with the objective exclusive approach toward TM (Gallardo-Gallardo et al., 2013), only those employees were identified as talented employees who showed the potential and capability to influence and act as change agents were identified as talented employees and selected for the program:

In my opinion, [the participation in the program] is about growing to realize that anything is possible. For 12 individuals, our eyes were opened. Through this, the company now has 12 more change agents. (Program participant 2011-2012)

By acting as change agents, talented employees contributed to the strategic renewal of the case company through the following means. First, they "worked on a business project, which can have a great impact on the company," as one of our respondents explained. In their project work, talented employees conceived and designed new business development and internal improvement initiatives (see Table I). Second, talented employees identified and created key positions that were of importance for the strategic renewal while working on the key projects (we will elaborate on key projects and key positions in more detail in the last section of our findings). Finally, by acting as change agents, talented employees cultivated a culture and proactive mentality for renewal across the case company. This occurred when the program participants realized that "anything was possible" and, as the number of the participants increased, this proactive mentality spread throughout the case company:

We've been talking about projects that have been getting better and better and attaining a higher business value. I've been talking about it being good management training, but I think one thing that I have realized throughout these years is that neither of these things is actually important for [the transformation]. Because the most important thing is that, from a cultural point of view, you create these change agents within the organization. One cannot help realizing what a fantastic way of driving cultural change this has been. (Member of the top management team)

You get people from all over the organization that are able to drive or to get involved in [the company] in a way that is quite extraordinary. You give people a network that is worldwide and not only this year's [program participants] but we continue the network for each generation. I think it's an extremely strong tool to work with what comes to driving change. (Program participant 2011-2012)

Consequently, our findings highlight that the role of TM in strategic renewal is to provide the conditions for the self-initiation of potential talented employees and for the development of the selected talented employees to act as change agents. As explained earlier, the open application procedure enabled those potential talented employees who recognized a change agent in themselves to volunteer and identified themselves as someone capable of driving change. In terms of their development, the program offered conditions where selected talented employees could "get out of their comfort zones" and work autonomously on, for example, their project work. In other words, talented employees were provided the freedom to develop their competences as they best saw fit and to work independently with areas they considered of major importance for strategic renewal.

\section{Process of talent management implementation during strategic renewal}

The business opportunities or challenges that talented employees worked with were "the foundation of the program." Hence, the process of TM implementation did not begin with the identification of key positions, which deviates from the definition of TM provided by Collings and Mellahi (2009). Instead key challenges or opportunities were identified and 
ER

42,1

assigned to talented employees in the form of project work. Said differently, talented employees were not initially selected to develop for a particular hierarchical or functional position. Instead we observed that during strategic renewal it was more meaningful to identify key projects - business opportunities or challenges - that talented employees would work on, and through which talented employees could contribute to the company's transformation. As it has been explained in the previous section, talented employees acted as self-initiated change agents, but a change agent was not a key position per $s e$ - rather, it was a role. The change agents drove the strategic renewal through project work, which focused on strategic priorities that subsequently enabled the case company to transform itself:

I think that's an opportunity to use some people that have put up their hands. Because they are volunteering to take the tests and see if they can make it. That means that we will have people that are trained slightly differently. It's work in a project to drive change. Because certain companies actually have change as their strategy. For me then, it's important that you choose intellectual projects that will make a difference. (Current CEO of the company)

The top management team of the case company was responsible for selecting the key projects to be executed during the program and assigning talented employees to teams to work with these projects. Key projects were assigned to talented employees as they had proven their capabilities during the selection process to bring in fresh perspectives and propose novel solutions to change the status quo in the case company. Nevertheless, talented employees executed the project work rather autonomously in their search for innovative solutions for their assignments. Altogether, 16 key projects (see Table I) were assigned to talented employees to work on during the five-year period that the program was maintained in the case company. The key projects focused both on the development of new business opportunities and internal improvement with themes such as innovation, global responsibility, supply chain improvement, product management and key account management. During the first phase of the program (2011-2012), the projects were rather broad in their scope and had a longer timeframe while in the subsequent phases of the program (2012-2016) the projects typically focused on a single division of the case company and its challenges, and had a shorter timeframe.

While participating in the program, talented employees were responsible for "helping the [top management team] to address some selected business challenges" and executing the project work. On some occasions, the project work included identification of a lacking capability or an organizational area in need of improvement. In these instances, during their project work, talented employees identified and created new key positions for a division of the case company or for the whole company that they believed would be of importance for strategic renewal.

Two examples of such positions emerging due to the case company lacking a capability or talented employees indicating an organizational area in need of improvement were product management and key account management. At the beginning of both projects, the scope of the project work did not entail creation of new positions or formulation of job descriptions. It was up to talented employees working with the specific projects to propose a position (e.g. product manager) or to create or update a job description for a position (e.g. key account manager), leading to new recruitments in the case company. Some talented employees ended up occupying these key positions after the program. Allowing talented employees to create key positions was thus seen as a crucial part of the process of TM implementation during strategic renewal:

I believe this is important for us as a company. We motivate people and allow them to develop in their own areas but we also challenge people so that they won't stay in their own area of expertise. It was a case of: "You go and test yourself in uncharted territories". (Executive VP of $\mathrm{X}$ division) 


\section{Discussion}

Strategic renewal involves critical changes to organizational activities and outputs as organizations respond to meet the needs of their environment (Albert et al., 2015). In this study, we forecasted the potential role of TM in strategic renewal and explored empirically our conceptualization by examining a TM program in a Finnish-Swedish MNC that was undergoing major strategic renewal. By outlining the role of TM in strategic renewal and investigating how the process of TM is implemented during strategic renewal, our study extends the existing knowledge on TM and offers a twofold contribution.

Our first contribution lies in distinguishing the role of TM during strategic renewal. Whereas "traditional" TM aims at "filling key positions with competent incumbents and ensuring their continued commitment" (Collings and Mellahi, 2009, p. 304), the findings of our study highlight that the role TM in strategic renewal is provide the conditions for talented employees to perform their responsibilities. By doing so, organizations may expect new business, products and services to be developed, which ultimately lead to the replacement of existing business, products and services (Agarwal and Helfat, 2009; Schmitt et al., 2018). In particular, the role of TM in strategic renewal is to provide talented employees with the freedom to develop their competences as talented employees and to empower them to work independently with key projects and areas they consider of major importance for strategic renewal. Accordingly, talented employees contribute to the organization's strategic renewal by acting as self-initiated change agents who conceive and design new business development and internal improvement initiatives, identify and create key positions and cultivate a culture and proactive mentality for renewal across the organization. We thus advocate that self-initiation among talented employees contributes to the successful execution of strategic renewal and is preferable over potential candidates being forced into a job or called upon. Hence, before talented employees are selected to participate in any TM program, which is an integral part of the process of TM implementation, they need to volunteer to participate. Furthermore, even though in our case company senior executives assigned key projects to the program participants, talented employees facilitated planned processes of change by taking responsibility for these key projects and creating their own key positions later. Therefore, acting as change agents enabled talented employees to look at what they did in a different way and bring about change to implement strategic renewal. This goes hand in hand with the definition of change agent as "a person who is responsible for initiating and maintaining a change effort" (Kendra and Taplin, 2004, p. 21). Hence, we argue that during strategic renewal talented employees need to act as self-initiated change agents by serving as prime movers who support strategic renewal (Weick and Quinn, 1999), "architecting" the forefront of strategic renewal (Tyson, 1995), and, subsequently, delivering strategic renewal (Ulrich, 1998). Overall, acting as self-initiated change agents enables talented employees to stimulate, facilitate and coordinate the organization's strategic renewal.

Our second contribution refers to extending the existing knowledge on how the process of TM is implemented during strategic renewal. Our results reveal that during strategic renewal, the identification of key positions becomes ambiguous and impractical. Instead, it is meaningful to identify key projects, which enable talented employees to focus on strategic priorities that consequently lead to strategic renewal. Thus, the differentiating factors in achieving strategic renewal become the projects not the positions, which enable talented employees to focus on strategic priorities that consequently lead to strategic renewal. This finding reveals that certain projects are more central and critical to strategic renewal than others. Hence, before focusing on individual talented employees and key positions, one needs to establish in which projects talented employees can have the greatest impact on strategic renewal since focusing solely on the individual talented employees and key projects can risk an over-investment in positions which will not have

Role of talent management 
ER

42,1

the potential to generate additional value after strategic renewal. A key challenge for organizations is then to identify the key projects. In addition to executing key projects, which are prearranged by the organization, talented employees may create key positions as part of their project work if they consider these positions crucial for strategic renewal. Overall, the process of TM implementation during strategic renewal involves the identification of key projects, which differentially contribute to the organization's strategic renewal, the identification of talented employees to execute these key projects, and the identification and creation of key positions.

\section{Practical implications}

Our study offers practical advice for top management and HR managers. First, the process of TM implementation during strategic renewal should start with the identification of "must-win-battles," for example, in the form of key projects that can have a more profound impact on change than the process of TM implementation where the identification of key positions occurs first.

Second, we recommend top management to allow and enable motivated potential talented employees to volunteer for the job of aiding company-wide changes. Self-initiation among potential talented employees may contribute to successful execution of strategic renewal and is preferable over talented employees being forced into a job or called upon.

Next, top management should provide talented employees with the space to come up with novel ideas and conceive new business opportunities. We believe that such an approach can mitigate resistance to change and allow the companies to tap into a greater pool of creativity and unforeseen ideas and opportunities.

Finally, and more specifically, as a guideline to the HR managers, we wish to emphasize the importance of transparent and spot-on evaluation criteria. It is of utmost value to ensure that all TM processes are transparent and have accurate evaluation criteria, especially when self-initiation among potential talented employees becomes an essential part of the process of TM implementation in an organization undergoing strategic renewal.

\section{Limitations and directions for future research}

Our study has certain limitations and we hope these limitations can open avenues for future investigation. First, we encourage scholars to explore the empirical settings characterized by change and unpredictability in more detail and larger samples, and thus explore the role of TM in other specific contexts and by quantitative methodologies. Specific contexts could include other types of organizational change than strategic renewal. For example, a vital research avenue exists in examining how TM is executed in the so-called new organizational forms of companies, e.g. non-hierarchical organizations with self-managing teams (Lee and Edmondson, 2017). Investigating companies where "there are no job titles, no job descriptions, and no employees called 'bosses'” (Puranam and Håkonsson, 2015, p. 2) can further illuminate the challenging question of how TM is conceived, implemented and developed in a broad variety of specific contexts.

Second, there is a limitation to the transferability of the results of this study beyond the cultural setting of the region in which the case company is embedded. Our case company is headquartered in both Finland and Sweden where power distance and organizational hierarchy are typically low, and employees possess high levels of independence and autonomy (Boye and Grönlund, 2018; Tukiainen, 2015). Perhaps due to their cultural background, talented employees studied were well equipped to participate in key projects and create key positions as part of their project work in the first place. Given that culture might be a boundary condition for theorizing here, future studies are encouraged to study other cultural settings, e.g. with a larger degree of power distance. 


\section{Conclusion}

While scholars and organizations adopt different approaches toward the meaning of talent, TM goals and TM outcomes, the internal context is the one most neglected in TM research (Gallardo-Gallardo and Thunnissen, 2016; Vaiman et al., 2017). In particular, the context of strategic renewal has to date been underrepresented in debates on TM. In this study, we echoed this criticism by acknowledging the decisive role of TM in achieving strategic renewal and elucidating how careful deployment of TM in the implementation of the organization's strategy can bring high economic value and contribute to the organization's strategic renewal.

\section{References}

Agarwal, R. and Helfat, C.E. (2009), "Strategic renewal of organizations", Organization Science, Vol. 20 No. 2, pp. 281-293.

Albert, D., Kreutzer, M. and Lechner, C. (2015), "Resolving the paradox of interdependency and strategic renewal in activity systems", Academy of Management Review, Vol. 40 No. 2, pp. 210-234.

Becker, B.E., Huselid, M.A. and Beatty, R.W. (2009), The Differentiated Workforce: Transforming Talent Into Strategic Impact, Harvard Business Press, Boston, MA.

Boye, K. and Grönlund, A. (2018), "Workplace skill investments - an early career glass ceiling? Job complexity and wages among young professionals in Sweden", Work, Employment and Society, Vol. 32 No. 2, pp. 368-386.

Burgelman, R.A. (1994), "Fading memories: a process theory of strategic business exit in dynamic environments", Administrative Science Quarterly, Vol. 39 No. 1, pp. 24-56.

Cascio, W.F. and Boudreau, J.W. (2016), "The search for global competence: from international HR to talent management", Journal of World Business, Vol. 51 No. 1, pp. 103-114.

Collings, D.G. and Isichei, M. (2018), "The shifting boundaries of global staffing: integrating global talent management, alternative forms of international assignments and non-employees into the discussion”, International Journal of Human Resource Management, Vol. 29 No. 1, pp. 165-187.

Collings, D.G. and Mellahi, K. (2009), "Strategic talent management: a review and research agenda", Human Resource Management Review, Vol. 19 No. 4, pp. 304-313.

Collings, D.G., Mellahi, K. and Cascio, W.F. (2017), The Oxford Handbook of Talent Management, Oxford University Press, Oxford.

Collings, D.G., Mellahi, K. and Cascio, W.F. (2019), "Global talent management and performance in multinational enterprises: a multilevel perspective", Journal of Management, Vol. 45 No. 2, pp. 540-566.

Corbin, J. and Strauss, A. (1990), "Grounded theory research: procedures, canons, and evaluative criteria”, Qualitative Sociology, Vol. 13 No. 1, pp. 3-21.

De Boeck, G., Meyers, M.C. and Dries, N. (2018), "Employee reactions to talent management: assumptions versus evidence", Journal of Organizational Behavior, Vol. 39 No. 2, pp. 199-213.

Eisenhardt, K.M. and Graebner, M.E. (2007), "Theory building from cases: opportunities and challenges", Academy of Management Journal, Vol. 50 No. 1, pp. 25-32.

Farndale, E., Scullion, H. and Sparrow, P. (2010), "The role of the corporate HR function in global talent management”, Journal of World Business, Vol. 45 No. 2, pp. 161-168.

Fitza, M.A. (2017), "How much do CEOs really matter? Reaffirming that the CEO effect is mostly due to chance", Strategic Management Journal, Vol. 38 No. 3, pp. 802-811.

Flier, B., Van Den Bosch, F.A.J. and Volberda, H. (2003), "Coevolution in the strategic renewal behaviour of British, Dutch and French financial incumbents: interaction of environmental selection, institutional effects, and managerial intentionality”, Journal of Management Studies, Vol. 40 No. 8, pp. 2163-2187.

Floyd, S.W. and Lane, P.J. (2000), "Strategizing throughout the organization: managing role conflict in strategic renewal”, Academy of Management Review, Vol. 25 No. 1, pp. 154-177. 
ER

42,1

Gallardo-Gallardo, E. and Thunnissen, M. (2016), "Standing on the shoulders of giants? A critical review of empirical talent management research", Employee Relations, Vol. 38 No. 1, pp. 31-56.

Gallardo-Gallardo, E., Dries, N. and González-Cruz, T.F. (2013), "What is the meaning of 'talent' in the world of work?”, Human Resource Management Review, Vol. 23 No. 4, pp. 290-300.

Gallardo-Gallardo, E., Nijs, S., Dries, N. and Gallo, P. (2015), "Towards an understanding of talent management as a phenomenon-driven field using bibliometric and content analysis", Human Resource Management Review, Vol. 25 No. 3, pp. 264-279.

Kendra, K.A. and Taplin, L.J. (2004), "Change agent competencies for information technology project managers", Consulting Psychology Journal: Practice \& Research, Vol. 56 No. 1, pp. 20-34.

Kreiner, G.E. (2016), “Tabula Geminus: a 'both/and' approach to coding and theorizing”, in Elsbach, K.D. and Kramer, R.M. (Eds), Handbook of Qualitative Organizational Research: Innovative Pathways and Methods, Routledge, New York, NY, pp. 350-361.

Krishnan, T.N. and Scullion, H. (2017), "Talent management and dynamic view of talent in small and medium enterprises", Human Resource Management Review, Vol. 27 No. 3, pp. 431-441.

Kwee, Z., Van Den Bosch, F.A.J. and Volberda, H. (2011), "The influence of top management team's corporate governance orientation on strategic renewal trajectories: a longitudinal analysis of Royal Dutch Shell plc, 1907-2004", Journal of Management Studies, Vol. 48 No. 5, pp. 984-1014.

Lee, M.Y. and Edmondson, A.C. (2017), "Self-managing organizations: exploring the limits of less-hierarchical organizing", Research in Organizational Behavior, Vol. 37, pp. 35-58.

McDonnell, A., Collings, D.G., Mellahi, K. and Schuler, R. (2017), "Talent management: a systematic review and future prospects", European Journal of International Management, Vol. 11 No. 1, pp. 86-128.

Meyers, M.C. and Van Woerkom, M. (2014), "The influence of underlying philosophies on talent management: theory, implications for practice, and research agenda", Journal of World Business, Vol. 49 No. 2, pp. 192-203.

Meyers, M.C., Van Woerkom, M. and Dries, N. (2013), "Talent - innate or acquired? Theoretical considerations and their implications for talent management", Human Resource Management Review, Vol. 23 No. 4, pp. 305-321.

Meyers, M.C., Van Woerkom, M., Paauwe, J. and Dries, N. (2019), "HR managers' talent philosophies: prevalence and relationships with perceived talent management practices", The International Journal of Human Resource Management, doi: 10.1080/09585192.2019.1579747.

Morris, S., Snell, S. and Björkman, I. (2016), "An architectural framework for global talent management”, Journal of International Business Studies, Vol. 47 No. 6, pp. 723-747.

Ocasio, W., Laamanen, T. and Vaara, E. (2018), "Communication and attention dynamics: an attentionbased view of strategic change”, Strategic Management Journal, Vol. 39 No. 1, pp. 155-167.

Oreg, S., Bartunek, J., Gayoung, L. and Boram, D. (2018), “An affect-based model of recipients' responses to organizational change events", Academy of Management Review, Vol. 43 No. 1, pp. 65-86.

Peltokorpi, V. and Froese, F. (2009), "Organizational expatriates and self-initiated expatriates: who adjusts better to work and life in Japan?", International Journal of Human Resource Management, Vol. 20 No. 5, pp. 1096-1112.

Pratap, S. and Saha, B. (2018), "Evolving efficacy of managerial capital, contesting managerial practices, and the process of strategic renewal", Strategic Management Journal, Vol. 39 No. 3, pp. 759-793.

Puranam, P. and Håkonsson, D.D. (2015), "Valve’s way”, Journal of Organization Design, Vol. 4 No. 2, pp. 2-4.

Riviere, M., Suder, G. and Bass, E.A. (2018), "Exploring the role of internationalization knowledge in fostering strategic renewal: a dynamic capabilities perspective", International Business Review, Vol. 27 No. 1, pp. 66-77.

Schmitt, A., Raisch, S. and Volberda, H. (2018), "Strategic renewal: past research, theoretical tensions and future challenges", International Journal of Management Reviews, Vol. 20 No. 1, pp. 81-98.

Schneider, M. (2018), "The impact of digitalization in the workplace", in Harteis, C. (Ed.), Digitalization of Production, Human Capital, and Organizational Capital, Springer, Cham, pp. 39-52. 
Siggelkow, N. (2007), "Persuasion with case studies", Academy of Management Journal, Vol. 50 No. 1, pp. 20-24.

Sparrow, P.R. and Makram, H. (2015), "What is the value of talent management? Building value-driven processes within a talent management architecture", Human Resource Management Review, Vol. 25 No. 3, pp. 249-263.

Teixeira, E.D.O. and Werther, W.B.J. (2013), "Resilience: continuous renewal of competitive advantages", Business Horizons, Vol. 56 No. 3, pp. 333-342.

Tukiainen, S. (2015), "Sensemaking of managing cultural differences in a Finnish-Polish project", Scandinavian Journal of Management, Vol. 31 No. 1, pp. 69-86.

Tyson, S. (1995), Human Resource Strategy: Towards a General Theory of HRM, Pitman Publishing, London.

Ulrich, D. (1998), “A new mandate for human resources”, Harvard Business Review, Vol. 76 No. 1, pp. 124-134.

Vaiman, V., Collings, D.G. and Scullion, H. (2017), “Contextualising talent management”, Journal of Organizational Effectiveness: People and Performance, Vol. 4 No. 4, pp. 294-297.

Van den Broek, J., Boselie, P. and Paauwe, J. (2018), "Cooperative innovation through a talent management pool: a qualitative study on coopetition in healthcare", European Journal of Management, Vol. 36 No. 1, pp. 135-144.

Wee, E.X.M. and Taylor, M.S. (2018), "Attention to change: a multilevel theory on the process of emergent continuous organizational change", Journal of Applied Psychology, Vol. 103 No. 1, pp. 1-13.

Weick, K.E. and Quinn, R.E. (1999), “Organizational change and development”, Annual Review of Psychology, Vol. 50 No. 1, pp. 361-386.

\section{Further reading}

Thunnissen, M., Boselie, P. and Fruytier, B. (2013), “A review of talent management: "infancy or adolescence?", The International Journal of Human Resource Management, Vol. 24 No. 9, pp. 1744-1761.

\section{Corresponding author}

Violetta Khoreva can be contacted at: violetta.khoreva@hanken.fi
Role of talent management 